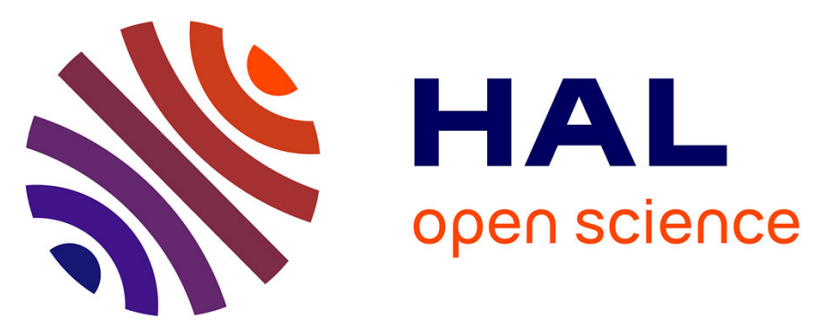

\title{
The range expansion of the pine processionary moth in a changing world: How a well understood multifactorial process could tangle up
}

\author{
Mathieu Laparie, Christelle Robinet, Jérôme Rousselet, Alain Roques
}

\section{> To cite this version:}

Mathieu Laparie, Christelle Robinet, Jérôme Rousselet, Alain Roques. The range expansion of the pine processionary moth in a changing world: How a well understood multifactorial process could tangle up. ICE 2016; XXV International Congress of Entomology, Sep 2016, Orlando, United States. 10.1603/ICE.2016.93550 . hal-01603601

\section{HAL Id: hal-01603601 \\ https://hal.science/hal-01603601}

Submitted on 5 Jun 2020

HAL is a multi-disciplinary open access archive for the deposit and dissemination of scientific research documents, whether they are published or not. The documents may come from teaching and research institutions in France or abroad, or from public or private research centers.
L'archive ouverte pluridisciplinaire HAL, est destinée au dépôt et à la diffusion de documents scientifiques de niveau recherche, publiés ou non, émanant des établissements d'enseignement et de recherche français ou étrangers, des laboratoires publics ou privés.

\section{다(1)(2)}

Distributed under a Creative Commons Attribution - ShareAlikel 4.0 International 


\section{Tuesday, September 27, 2016}

02:15 PM - 02:30 PM

Introduction: While distributional changes associated with climate change have been widely acknowledged in ectotherms in the light of their ecophysiological limits, causal relationships with range shifts have still rarely been demonstrated. In the pine processionary moth, a winter-developing insect, combined experimental and modelling evidence have elucidated the mechanisms in which average winter warming has lowered barriers to expansion. Nonetheless, warming may also alter life cycles, or vulnerable instars may be subjected to new stressors associated with climate fluctuations. Comprehensive responses to such varied conditions are not fully untangled yet, and the spread may be more complex than initially thought due to mixed effects of future climate change, its spatial dependency, and population differentiations.

Methods: This presentation will be based upon published work on this study system, spanning a number of techniques ranging from thermal biology under controlled conditions and semi-natural experiments to field surveys and in silico approaches.

Results/Conclusion: Tolerance to acute cold is considered high enough to withstand usual minimal temperatures near front edges, but larval susceptibility to cumulative chill injury and thermal induction of foraging were evidenced. Both processes impair colony survival of this gregarious species under natural conditions. Spread simulations from climate records and feeding thresholds showed that warmer winters have opened previously unsuitable areas that match those actually neo-colonized. However, thermal constraints depend on genotypes and life stages, which have yet to be considered. Demographic outcomes of climate variations are thus contingent on geography and phenology, the latter being known to vary among populations.

doi: 10.1603/ICE.2016.93550

\section{Authors}

Mathieu Laparie

INRA

\section{Christelle Robinet}

INRA

Jérôme Rousselet

INRA

Alain Roques

INRA

\section{View Related Events}

Symposium: 319 Symposium: Forest Insect Invasions in a Changing Climate: Mechanisms and Risks

Program: Symposium

Day: Tuesday, September 27, 2016 